\title{
Nurses perception to the implementation of therapeutic communication in intensive care unit
}

\author{
Neny Ariyanti ${ }^{1}$, Sri Suparti ${ }^{2}$ \\ ${ }^{1,2}$ Health Faculty, Universitas Muhammadiyah Purwokerto
}

\begin{tabular}{l}
\hline ARTICLE INFO \\
\hline Article history: \\
Received: August 9, 2020 \\
Revised: August 20, 2020 \\
Accepted: August 30, 2020 \\
\hline
\end{tabular}

Keywords:

Therapeutic Communication, Intensive Room, Nurses

\begin{abstract}
Therapeutic communication in intensive rooms was a therapeutic communication initiated by nurses to patients with intensive conditions whichrequired critical thinking, fast and precise measures in coping with each patient's needs. To figure out the nurses' perceptions of the application of therapeutic communication in Intensive room. The study was qualitative phenomenological study, involving eight intensive care nurses participants from IGD, HCU, ICU and NICU. The inclusion criteria were nurses who had worked at least 1 year in the intensive unit, with a minimum education level of bachelor in nursing, through in-depth interviews. The data were analyzed using the Colaizzi method. There were 4 themes identified in the nurses' perception of the application of therapeutic communication: communication to help the healing process, adaptation and information, stages, technical and benefits of communication. The communication which had not been widely explored wasthe one to help the patients' adaptation process to illness and the communication in emergency situations. The therapeutic communication model is adjusted to the goals and characteristics of patients. Especially for the patients in emergency condition, the nurses are required to have sensitivity and communication skills which have not been sufficiently explored. The communication tends to be directional, not interactive, while the non-verbal communication has not been carried out optimally.
\end{abstract}

This work is licensed under a Creative Commons Attribution 4.0 International License.

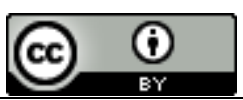

\section{Corresponding Author:}

Sri Suparti,

Fakultas Ilmu Kesehatan,

Universitas Muhammadiyah Purwokerto

Dusun II, Sokaraja Kulon, Kec. Sokaraja, Kabupaten Banyumas, Jawa Tengah, 53181, Indonesia

email address: srisuparti@ump.ac.id

\section{INTRODUCTION}

The Therapeutic communication is an aspect that affects the quality of health services, where everyone has the same right to access health services (Health Law No. 36 of 2009, Article 5). It is one of the service standards in hospital accreditation, which is the goal of the safety of the patient(National Hospital Accreditation Standards - SNARS, 2018). Therapeutic communication is communication carried out by nurses or other medical personnel with patients or nurses with other medical personnel, and with the patient's family based on mutual trust as the art of healing [1].

Communication in the health service team has an important role in achieving good nursing and health service outcomes for patients [2]. This is supported by the inclusion of therapeutic communication as an independent intervention that can carried out by each nurse in supporting other interventions in resolving nursing problems in the part of patients. It has beenunderlined that communication is contained in the Indonesian Nursing Intervention Standards (SIKI) (Indonesian National Nurses Association (PPNI, 2018) and Nursing Interventions Classification (NIC) which are 2 basic guidelines in the preparation of nursing interventions used today [3].

The purposes of communication related to the quality of nursing care are the patient's safety and the patient's satisfaction. Tthe relationship between communication factors and patient safety incidents shows that 
good and effective communication can prevent patient safety incidents from occurring. Effective communication will reduce incidents that risk the patient's safety and increasing the patient's satisfaction (Audrey M. Burgener, 2017), decreasing the patient family's anxiety and reducing errors in medical decision making made by the patient's family [4]. The type of communication in the intensive room consists of two aspects, i.e. the communication between the practitioner and the patient/family and the importance of the communication process with the family for the patient's recovery [5].

Several studies related to the implementation of therapeutic communication in the intensive room show poor results, including therapeutic communication in the ER at the stage of doubt which means that it has not reached the level of patient satisfaction [6], job satisfaction, work motivation, and work climate, support from friends and support from the head of the room [7] the character of the executor includes gender, age, the patient's emergency condition [8], physical and mental fatigue, language, leadership support and hospital management, support facilities and job awards [9] In fact, it is mentioned that communication is a factor that affects LOS (Length of Stay) in the ER [10]. Communication in Emergency is very complex and prone to miss communication. The most dominant specific problem is the result of a lack of knowledge on transitional conditions, inconsistency of medical records, large numbers of patients, long working hours, and decreased focus of officers [11].

In the current development of technology and information, where health services focus on patients, the demands of implementing therapeutic communication are increasingly needed in relation to the patient's need for good quality health services. The poor implementation of therapeutic communication can result in a decrease in the quality of nursing care, LOS, and an increased risk of patient safety incidents, patient/family anxiety. Because of the important role of therapeutic communication in the success and quality of health services, therapeutic communication is a national and international issue which is still being discussed and researched. This study aims to explore nurses' perceptions about the application of therapeutic communication in the intensive room of Banyumas Regional Hospital. Intensive room nurses regarding the application of therapeutic communication is very subjective. Hence, the researchers choose a qualitative method with a phenomenological approach. It is hoped that this research will find novelty in the application of therapeutic communication in the intensive room.

\section{RESEARCH METHOD}

This qualitative research using phenomenology approach took place in 4 intensive rooms of Banyumas Regional Hospital, namely IGD, HCU, ICU, and NICU. The study involved 8 participants who were nurses in the intensive room, with an average length of work in the room of more than 1 year, aged between $40-45$ years, with an educational background of S1 nursing. Data collection was obtained using in-depth interviews using voice recorder. Data analysis used the colaizzi approach, which includes 7 stages, namely; transcribing and translating the results of interviews, digging important statements, formulating the meaning of important statements, organizing the meanings formulated in aggregate into theme groups, writing complete descriptions of existing phenomena, identifying fundamental statements, and validating fundamental statements of each participant [10].

\section{RESULTS AND DISCUSSIONS}

All the results of the interviews with participants were then analyzed by Colaizzi method; transcribing and translating the results of the interviews by writing the interviews in complete verbatim form, and extracting important statements.At this stage the researcher made the interview result matrix, formulated the meaning of the significant statements, the researcher identified the keywords of each answer participants, giving the formal meaning of important statements into thematic groups, the researcher classifies several keywords into a theme, from the existing themes the researcher fully describes a phenomenon, then the researcher identifies the core concepts related to the emerging themes, validates a complete description of a phenomenon with each participant [12].

From the themes proposed by the researcher, as material for interviews with the participants, four themes were obtained from the answers of the participants. Those were :

3.1. Communication as a Process to help patient's healing; Adaptation and Information

"In my opinion, therapeutic communication is communication made by nurses to help the patient's healing process, where nurses need skills to carry out this therapeutic communication, in general.” (P1).

"... Helping patients in dealing with stress and illness means that we hope that the patients treated here are more adaptable and enthusiastic in undergoing their treatment...”(P5).

"... The nurse's ability to convey information to the patient, with the aim of improving the patient's health ..." (P7).

\subsection{Communication Stages}


“... My shift schedule for tonight has been completed. The next morning, you, Sir, will be looked after by nurse $L$ and nurse S.If there is something needed during treatment, you can call them for any help,Okay Sir? Alrigh, we will leave to change shift..." (P2).

"Actually, therapeutic communication was originally intended to study or analyze the patient's condition and complaints. After that, nursing diagnoses would emerge. From nursing diagnoses, interventions and actions would be made to solve patient problems so basically therapeutic communication aims to solve patient problems" (P4).

\subsection{Therapeutic Communication Technical}

"If it is an emergency, we will immediately take action. Save the patient first. We don't have time to communicate ... if it is an emergency, it is impossible for us to communicate first. We take action first" (Pl).

"Of course there are difficulties ..., especially in the ER ... patients who come in a row, with a limited number of officers, make the application of therapeutic communication less effective, especially in our ER patients who come with emergency conditions ... we are tired, we are less than optimal in doing therapeutic communication, ..." $"(P 3)$.

"Because most patients are not conscious, the feedback is lacking.So, communication occurs more in one direction ... those who are unconscious, are still on a ventilator.So, we can observe the pain through his vital signs, from his facial expressions" (P2).

"... Most of the HCU patients are patients with chronic diseases, who have been experiencing pain for years. HCU patients are more dominant in psychological or psychological complaints, who are hopeless, have lost hope of recovery, lack of motivation and support system." (P6)

\subsection{Benefits of Therapeutic communication in the intensive room of Banyumas Regional Hospital}

"... Even though in a state of decreased consciousness, sometimes something is still remembered, this makes the patient feel cared for and calm" (P2)

"... For example, neonatals who used to cry and we hold and we hug them, many become calm... Or nenonatal who are lethargic, we give motivation and touch to survive, many then show improvement, for example saturation rises, HR increases, like that. (P7)

\subsection{Therapeutic communication regarding patient safety}

"... For example identification;Sir, this is correct... it must be correct ... the use of high alert drugs, you have to double check for it ... (P2)

"... with therapeutic communication we can save our patients, meaning that there are no incidents that we do not want while being treated ..." (P8).

Research on nurses' perceptions of the application of therapeutic communication in the intensive room of Banyumas Regional Hospital, led to 4 findings which became a separate theme. First, based on an understanding of the meaning and purpose of therapeutic communication, the participants have several perceptions including, therapeutic communication is a skill or ability of the nurses to communicate with patients or patients' families, which aims to help the patient's healing process. Focuses on consciously planned communication where activities and goals are focused on healing the patient, helping the patient's adaptation process. Defines it as face to face interactionwhich focuses on improving emotions and physical and family abilities to treat the illness, and also the process of delivering information.States that communication is the delivery of social interaction messages.

Second, in terms of the stages and the expected results or outputs from the therapeutic communication which is built between nurses and patients or the patient's family, it was found that a phenomenon that therapeutic communication has two main objectives, namely therapeutic communication with a general purpose, with the purposeof building a trusting relationship between patient and nurse, increasing patient openness, providing a sense of security and comfort, both for nurses and for patients in providing nursing care.

Stated that by introducing herself, nurses have been open to clients and this is expected to encourage clients to open up.Another goal is therapeutic communication specifically as a stage in the nursing care process. In this finding or phenomenon, nurses build a special therapeutic communication system as a means to carry out the nursing process, which includes assessment, the process of collecting and collecting patient data, formulating nursing diagnoses, compiling action plans, continuing the implementation process to the evaluation process [13] said that therapeutic communication is a give and take relationship between nurses and patients in nursing services.

Third, from each of the intensive rooms used in this study, namely IGD, HCU, ICU, and NICU, it was found that there were findings of technical differences in the application of therapeutic communication related to the patient's condition in that room, although with the same goal of improving or healing the patient. The emphasis of therapeutic communication in this theme is on techniques and therapeutic attitudes which are 
applied to intensive patients with different conditions. In unconscious patients, the dominant therapeutic communication used in patients is unidirectional, non-verbal, and written communication.In the world of nursing we also learn that communication can occur through words, written, spoken and non-verbal communication such as body language [14]. In patients with chronic or chronic illness conditions, therapeutic communication is more effective in using two-way communication, listening more to what the patient says about their feelings and pain and supporting the achievement of the patient's optimal condition, namely positive feelings and positive emotions about the pain.According to communication is an adaptation process between two or more people that aims to combine ideas, understanding, and attention. For patients in an emergency/critical condition, the therapeutic communication done is more questioning, especially regarding the main complaints. It is more often two-way communication with the patient's family. It seems that therapeutic communication in emergency conditions is not optimal. Arguesthat therapeutic communication in an emergency situation is different, because it focuses on the action to be performed.

Fourth, the nurse's perception focuses on the benefits of therapeutic communication, especially for patient's improvement/healing. This point was conveyed and acknowledged by all participants in this study. The communication process affects the improvement of the patient's condition. The relationship between the therapeutic communication and the condition of the patient can be direct or indirect for the nurse and the patient. Indirectly, adequate therapeutic communication will have an impact on the emergence of trust in nurses, a sense of security and comfort in patients because the information conveyed in therapeutic communication is well received by the patients, which in turn resulting in the patient's willingnessto provide accurate information.In a direct way, it is related to the accurate data and information obtained from the communication. With these data, the problem formulation will be correct, and the action plan to measure is effective. This is also important for better and more precise evaluation of the patient to come into recovery of the patient's condition. An effective communication significantly reduces anxiety in the families of the patients being treated in the ER. In addition, it also reduces the occurrence of inappropriate decision making by the patient's family.

This study relates therapeutic communication with patient safety. The participants agreed that with good therapeutic communication, it will avoid the occurrence of patient's safety incidents. With the patient sufficientsafety system at Banyumas Regional Hospital, all efforts are on the nurseto comply and to always carry out any risky actions against safety incidents, in accordance with existing standard operational procedures by building effective communication [15]. From the four themes of findings, it can be seen that therapeutic communication is not only limited to the understanding and the stages in carrying out nursing care, but is broader in terms of technical and more comprehensive objectives and benefits, including bio-psycho-socio of the patient. Its implementation requires ideas, modification and critical thinking of nurses, especially those working in the intensive room. If the nurses and other medical personnels have an effective communication, adherence, habits in implementing the SOP of the patient safety, the patients in the hospital will be treated well; the hospital will be comfortable, safe, and also satisfying for all, as the motto saying "Your Safety, Recovery and Satisfaction is Our Happiness".

\section{CONCLUSION}

The study on nurses' perceptions of therapeutic communication in the intensive room has found out four theme findings. They are the understanding, stages, and technical applications and benefits of therapeutic communication. It was found that therapeutic communication in emergency conditions was not optimal. Therapeutic communication in the emergency room had not been carried out completely and optimally due to various obstacles in the emergency room, including the emergency condition of the patient, the number of visits, the limited number of officers and the relatively short hospitalization time. The nursesthere have not realized and explored the potential and ability to communicate in this condition. In emergency conditions, the communication is only one-way due to the situation. Meanwhile, other forms of communication can be done, like non-verbal communication (body language, facial expressions). The accuracy of reacting during an emergency and their communication skills need to be trained. It is suggested for a further research on this topic. The nurses, especially those in the intensive units, need for periodic training on the communication, and they also have to improve their critical thinking skills and communication skills.

\section{Acknowledgements}

The researcherswant to send their deepest gratitude to all parties who have helped in carrying out this research, including the supervisors and all lecturers at UMP Purwokerto and all the parties involved in Banyumas Regional Hospital. 


\section{REFERENCES}

[1] A. Nasir, Komunkasi Dalam Keperawatan Teori dan Aplikasi, Jakarta: Salemba Medika, 2011.

[2] K. Amelia, T. Yanny and I. Silwi, Keperawatan Gawat darurat dan Bencana Sheehy, Singapura: Elsevier, 2018.

[3] H. K. Butcher, G. M. Bulechek and Dochterman, Nursing Interventions classification (NIC)-E-Book, Elsevier Health Sciences, 2018.

[4] Lukmanulhakim, Suryani and A. Anna, "The Relationship of Communication of Nurses and Level Anxiety of Patient's family in Emergency Room dr. Drajat Prawiranegara Hospital," Published master thesis, Serang, Banten, Indonesia, 2018.

[5] A. V. Zani, "Communicative process in the Emergency Departement between Nursing Staff and Patients," State University Londrina, Brazil, 2014.

[6] M. P. Kusumo, "Pengaruh Komunikasi Terapeutik Perawat Terhadap Kepuasan Pasien di Rawat Jalan RSUD Jogja," Jurnal Medicoeticolegal dan Manajemen Rumah Sakit, vol. 6, no. 1, pp. 72-81, 2017.

[7] N. Fitria and Z. Shaluhiyah, "Analisis Pelaksanaan Komunikasi Terapeutik Perawat di Ruang Rawat Inap RS Pemerintah dan RS Swasta," Jurnal Promosi Kesehatan Indonesia, vol. 12, no. 2, pp. 191208, 2016.

[8] A. Dhaneswari, "Komunikasi antara perawat terhadap pasien di IGD RSU Jati Husada Karanganyar," Commonline Departemen Komunikasi, vol. 4, no. 2, pp. 425-436, 2015.

[9] P. Agustrianti, "Analisis Faktor-Faktor yang Berhubungan dengan Efektivitas Komunikasi Perawat dan Pasien di Ruang Rawat Inap Rumah Sakit Harapan Mulia Kabupaten Bekasi tahun 2015," Jurnal Administrasi Rumah Sakit Indonesia, vol. 2, no. 1, 2018.

[10] H. I. Kusumawati, J. Magarey and P. Rasmussen, "Analysis of factors influencing length of stay in the Emergency Department in public hospital, Yogyakarta, Indonesia," Australasian emergency care, vol. 22, no. 3, pp. 174-179, 2019.

[11] J. K. Matthiessen and K. A. Murray, "Factors Affecting Communication in Emergency Departemens : Doctors and Nurse's Perceptions of Communication in a Trilingual ED in Hong Kong," The Hong Kong Polytecnic University, 2015.

[12] Suryani, Welch and Cox, "Penerapan Metode Colaizzi dalam Melakukan Penelitian di Dua Bahasa," Universitas Padjajaran, Bandung, 2016.

[13] S. Aswad, Mulyadi and J. S. Lolong, "Hubungan Komunikasi Terapeutik Perawat dengan Kepuasan Pasien di Instalasi Gawat Darurat RSUD Dr. H. Chasan Boesoirie Ternate," Jurnal ejournal Keperawatan, vol. 3, no. 2, pp. 1-8, 2015.

[14] P. Agustrianti, "Analisis Faktor-Faktor yang Berhubungan dengan Efektivitas Komunikasi Perawat dan Pasien di Ruang Rawat Inap Rumah Sakit Harapan Mulia Kabupaten Bekasi Tahun 2015," Jurnal Administrasi Rumah Sakit Indonesia, vol. 2, no. 1, 20018.

[15] A. M. Burgener, "Enhancing Communication to Improve Patient Safety to Increase Patient Satisfaction," Southern Illinois Univercity Carbandale, 2017. 